\title{
Landslide Susceptibility Region Mapping Using GIS, Analytic Hierarchy Process Model, and Multi-Criteria Analysis at the Chemoga Watershed, Upper Blue Nile, Ethiopia
}

\author{
Hunegnaw Desalegn ( $\square$ tig2124@gmail.com ) \\ Debre Markos University College of Technology \\ Arega Mulu \\ Debre Markos University College of Technology \\ Banchiamlak Damtew \\ Debre Markos University College of Technology
}

\section{Research Article}

Keywords: GIS, Multi-criteria, AHP, DEM, landslide susceptibility mapping

Posted Date: November 17th, 2021

DOI: https://doi.org/10.21203/rs.3.rs-1046034/v1

License: (c) (i) This work is licensed under a Creative Commons Attribution 4.0 International License. Read Full License 


\section{Abstract}

Landslide susceptibility consists of an essential component in the day-to-day activity of human beings. A landslide incident typically happening at a low rate of recurrence when compared and in contrast to other events. This might be generated into main natural catastrophes relating to widespread and undesirable sound effects. Therefore, based on this perception and merging with the expert approach that has been the propensity to encourage and defy extreme physical development to generate a methodology to use GIS, AHP, and Multi-criteria decision analysis for landslide susceptibility maps. A geographic information system is a grouping with additional methods, such as the method for multi-criteria decision making. MCDA techniques are applied under such circumstances to categorize and class decisions for successive comprehensive estimation or else to state possible from impossible potentiality with various landslides. Analytical Hierarchy Process (AHP) constructively applies for conveying influence to different criteria within Multicriteria decision analysis. The causative landslide weights utilized within this research were elevation, slope, aspect, Soil type, Lithology, Distance to stream, Land use land cover, rainfall and drainage density achieved from various sources. Subsequently, to explain the significance of each constraint into landslide susceptibility weights of all factors were finding out AHP technique. Generally, landslide susceptibility maps of all factors were multiplied to their weights to acquire with the AHP technique. The result showed that the AHP methods are comparatively good quality estimators of landslide susceptibility identification within the chemoga watershed. As the result, the Chemoga watershed area of landslide susceptibility map classes was classified as $46.52 \%, 13.83 \% .18 .71 \%, 15.39 \%$, and $5.55 \%$ of the occurred landslide fall to very low, low, moderate, high, and very high susceptibility zones respectively. Performance and accuracy of modeled maps have been established using GPS field data and Google earth data landslide map and Area under Curve (AUC) of the Receiver Operating Characteristic curve (ROC). The research outcomes inveterate the very good test consistency of the generated maps. As the result, validation depends on the ROC specifies the accuracy of the map formed with the AHP merged through weighted overly method illustrated very good accuracy of AUC value $81.45 \%$.

\section{Introduction}

Landslides are expected sequences that might be generated directly or not directly through natural as well as human day-to-day activities (Kıncal et al., 2017). Unnecessary consequences on human life and economic activity out coming from landslides have been observed in the world. Just about the world as well as within the moorlands, landslide is well thought-out one of the main difficult geomorphological incidents (Senouci et al., 2021). They are acknowledged as the major intimidation to human lives, human activity, and human injuries for all economically, socially, politically as well as environmental aspects (Wang et al., 2015).

Earth accumulation movements, resulting from natural conditions associated with topography, geological structure, natural deference vegetation index, and hydrogeology, are districted as landslides. In developing countries like Ethiopia, most of the time landslides occurred within natural activity contain high precipitation, seismic activity and volcanic eruption and human being activities such as land use alteration, deforestation, dig out, improperly tracing work, modify within the slope profile and distance to a road (Wahono, 2010).

As a result, researchers and government workers in different countries had been supposed to be susceptible to natural catastrophes. In addition to this premeditated hazard early warning methods and vulnerability risk analysis to be control fatality and reduce harm to property. The cause of avalanche event, high hazard landslide area was recognized and noticed within a 1980s along with landslide vulnerability investigations have been exercised the function of reviewed level of hazard within landslide hotspot area. In the past, numerous researchers have been contrived to build up well-organized systems to produce dependable vulnerability maps. Those approaches contain frequency ratio(Lee et al., 2016), logistic regression (Chen et al., 2017), judgment vegetations (Lee and Park, 2013), fuzzy logic (Oh et al., 2017), neuro fuzzy systems (Aghdam et al., 2016), support vector machines (Pradhan, 2013), artificial neural networks (Conforti et al., 2014) and multi-method approach (Yalcin et al., 2011).

Problems caused by landslides varied starting topsoil loss to human fatality and to modify the form of land for instance reasoning avalanche barriers which happen massive landslide wedges a stream flow with cause of lake, thus kind of barrier commonly take place within tectonically lively hills that basis unexpected landslide (Noorollahi et al., 2018).

Generally, this research including the factor of mapping was performed to create landslide susceptibility maps depending on GIS-based spatial multicriteria techniques. The major landslide susceptibility causing factors like elevation, slope, aspect, Soil type, Lithology, Distance to stream, Land use land cover, rainfall, plus drainage density had applied to landslide susceptibility identification. Weights for all factors are assigned with AHP based on their influential lying on landslide incidence. The landslide susceptibility maps have been generated with weighted overlay techniques along with classified in five prone ranks specifically, very low, low, moderate, high, and very high.

\section{Materials And Methods}

\subsection{Description of the Study Area}

The studies were carried out at the Chemoga watershed which was located in the East Gojjam Zone of the Amhara region. Geographically Chemoga watersheds are situated at latitude of $14^{\circ} 0 \otimes 0^{\prime \prime}$ to $31^{\circ} 40 \otimes 0^{\prime \prime}$ North and longitude of $14^{\circ} 25 \otimes 0^{\prime \prime}$ to $76^{\circ} 35 \otimes 0^{\prime \prime}$ East. The whole area of the Chemoga watershed is about $1183.62 \mathrm{~km}^{2}$ and shown in Figure 1. The Chemoga watersheds are the headstreams of the Blue Nile River. The mean altitudes of areas are $2395 \mathrm{~m}$ above means level with mean yearly precipitation was $1376 \mathrm{~mm}$. The yearly mean temperature also differs from $10.8^{\circ} \mathrm{C}$ to $23.1^{\circ} \mathrm{C}$ through a mean value $16.95^{\circ} \mathrm{C}$. 


\subsection{Data collection and methodology}

\subsubsection{Topography}

Topographic-related factors such as elevations were generated from the $30 \mathrm{~m} \star 30 \mathrm{~m}$ Digital Elevation Model of research region. Elevations are broadly applied for evaluation of landslide susceptibility. Elevation difference might be correlated in the direction of unlike environmental situates like rainfall and plants category (Dou et al., 2015). The 30m^30m digital elevation model (DEM) gated as of Geospatial Information Authority (GIA) of the Amhara region (GIS) was applied to generate elevation. Chemoga watershed is characterized by highly rugged and undulating topography on the upper part. $A$ large portion of the watershed falls in including Flat to almost flat terrain and gently flat to undulating terrain (43.25\%) and Gently flat to undulating terrain and rolling terrain (4.03\%) slope classes as indicated in Table 1. The elevation of the Chemoga watershed differs from 858 to 3932 meters above sea level (Figure 2).

Table 1

Percent of the area coverage for elevation in chemoga Watershed

\begin{tabular}{|lll|}
\hline Elevation(m.asl) & Area $\left(\mathrm{km}^{2}\right)$ & Percent (\%) \\
\hline $858-1502$ & 287.80 & 24.31 \\
\hline $1502-2032$ & 233.19 & 19.70 \\
\hline $2032-2501$ & 511.94 & 43.25 \\
\hline $2501-3048$ & 103.20 & 8.72 \\
\hline $3048-3932$ & 47.67 & 4.03 \\
\hline
\end{tabular}

\subsubsection{Slope}

Topographic related factors such as slopes were generated $30 \mathrm{~m} * 30 \mathrm{~m}$ Digital Elevation Model of research district. Slopes are supposed when major factor within the landslide susceptibility maps for a reason that slopes have been the direct consequence on landslides development; consequently, which was commonly applied into the landslide susceptibility maps (Ntelis et al., 2019). Slope angles are normally supposed as the main significant causes for landslide since it organizes shear forces acting on prominence slope (Kalantar et al., 2018). The slopes of research region produced from 10meter contour intervals feature class which was digitized from the DEM degree by means of extra alteration in GIS setting. Characters were altered shape file by 3D Analyst Tools in raster surface. A slope attributes classes were altered further to raster with conversion tool. From raster reclass gradient raster layer was more reclassifying in five sub-groups through normal alignmenting methods (natural breaks) since illustrated Figure 3 \& Table 2.

Table 2

Slope ranges of Chemoga watershed (Travaglia et al., 2001)

\begin{tabular}{|lll|}
\hline S/N & Slope class (\%) & Class Name \\
\hline 1 & $0-2$ & Flat to almost flat terrain \\
\hline 2 & $2-10$ & Gently flat to undulating terrain \\
\hline 3 & $10-15$ & Rolling terrain \\
\hline 4 & $15-30$ & Hilly terrain \\
\hline 5 & $>30$ & Steep dissented to mountainous \\
\hline
\end{tabular}

\subsubsection{Soil type}

Landslides commonly happen in highland and undulating areas through thick soil or weathered rock as well as within volcanic landscape more than moist tropical zone. Landslide within volcanic landscape happens when the deteriorating of highland topography because of volcanic parent rocks influence hydrothermal modification development. Landslides take place in the hydrothermal modification area to be able to subject with the bulge clay mineral bearing hydrothermal variation forms, immerse slope angle plus top rocks (Noviyanto et al., 2020). For this research soil data, FAO soil groups were gathered from Ministry of Water, Irrigation and Electric (MoWIE). Based on this, eleven major soil types were distinguished at the Chemoga watershed such as Chromic Cambisols, Chromic Luvisol, Eutric Nitosols, Lithosol, Rendzians, rock surface, Orthic Acrisols, Dystric Nitosols, Eutric Cambisols, Chromic Vertisols, and Pelvic Vertisols (Figure 4). From these soils, Pellic Vertisols (22.60\%) were dominant next to Eutric Nitosols (19.49\%) as presented in Table 3 . 
Table 3

Percent of the area coverage for the soil type in chemoga Watershed

\begin{tabular}{|llll|}
\hline S/N & Soil type & Area $\left(\mathrm{km}^{2}\right)$ & Percent (\%) \\
\hline 0 & Chromic Cambisols & 4.88 & 0.41 \\
\hline 1 & Chromic Luvisols & 133.15 & 11.25 \\
\hline 2 & Chromic Vertisols & 59.04 & 4.99 \\
\hline 3 & Dystric Nitosols & 212.63 & 17.96 \\
\hline 4 & Eutric Cambisols & 38.87 & 3.28 \\
\hline 5 & Eutric Nitosols & 230.68 & 19.49 \\
\hline 6 & Lithosols & 59.24 & 5.00 \\
\hline 7 & Orthic Acrisols & 27.61 & 2.33 \\
\hline 8 & Pelvic Vertisols & 267.56 & 22.60 \\
\hline 9 & Rendzians & 136.85 & 11.56 \\
\hline 10 & rock surface & 13.11 & 1.11 \\
\hline
\end{tabular}

\subsubsection{Land use land cover}

Land use land covers are a main factor that is accountable for activating the happening of landslides. In general, slopes with no plant cover along with troubled tree-plants are extra exposed to landslide within difference planting regions which approach to decrease action of climatic driving force like precipitation, consequently controlling attrition because of natural waterfront afforded with tree roots. The settlement, Forest and agriculture practice were the major land use/land cover ranks within the research area, but, increasing urban have intruded with a wooded region since additional lands were removed and rendering to climatic constituents. In general, gradients through impenetrable plantation cover could be fewer exposed incidence of low landslide rather than infertile gradients, whereas each constraints continue invariable (Gbadebo et al., 2018).

Diverse types of land use land cover types might influence steadiness gradient because land use land cover can alter hydrological operation of hill slopes, rainfall partition, penetration characters, and run-off invention in addition to the shear strength of soil characteristics (Chen et al., 2019). For the time being, on the contrary numerous ecological causes like geological structures as well as lithology, land use/land cover could be modified seasonally or in a short period for the reason of the weights from human activities and nature (Reichenbach, 2014). The system of land use in an area significantly influences the pattern and rate of landsliding. The land use land cover types identified from a region which clipped using GIS of Chemoga watershed were categorized under nine classes (Figure 5). The dominant land use/land cover was cultivated land (57.71\%) and grassland (19.10 \%) of the total watershed area (Table 4).

Table 4

Percent of the area coverage for land use/cover in chemoga Watershed

\begin{tabular}{|llll|}
\hline S/N & Land use/cover & Area(km $\left.{ }^{2}\right)$ & Percent (\%) \\
\hline 1 & Afro-alpine & 5.693 & 0.48 \\
\hline 2 & Bare land & 13.562 & 1.15 \\
\hline 3 & Cultivation & 683.156 & 57.71 \\
\hline 5 & Grassland & 226.065 & 19.10 \\
\hline 6 & Natural Forest & 0.84 & 0.07 \\
\hline 7 & Shrublation & 22.732 & 1.92 \\
\hline 8 & Wetland & 13.889 & 1.17 \\
\hline 9 & Woodland & 204.677 & 17.29 \\
\hline
\end{tabular}

\subsubsection{Aspect}

Topographic related factors such as aspects were generated from the $30 \mathrm{~m} \star 30 \mathrm{~m}$ DEM of a research area. A layer for aspects were depending on DEM. Aspect symbolizes the angle among the Geographic North and flat plain for convinced point and is categorizes with ten orientations. The aspect of the

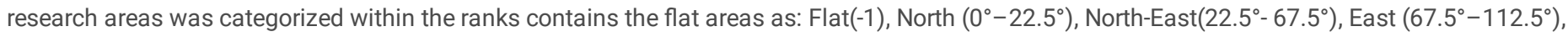
South-East $\left(112.5^{\circ}-157.5^{\circ}\right)$, South $\left(157.5^{\circ}-202.5^{\circ}\right)$, South-West $\left(202.5^{\circ}-247.5^{\circ}\right)$, West $\left(247.5^{\circ}-292.5^{\circ}\right)$, North- West $\left(292.5^{\circ}-337.5^{\circ}\right)$ and North $\left(337.5^{-}\right.$ 
$360^{\circ}$ ) in (Figure 6). Aspects were a significant factors within organizing landslide susceptibility maps (Gbadebo et al., 2018). Aspect correlated constraints like disclosure to sunlight, exposure to air, rainfall, and dissimilarities might be possibly preventing the incidence of landslides (Rabby et al., 2020).

\subsubsection{Distance to stream}

The closeness of slope to river direction was a significant factor to states landscape movement of the study areas and a pointer of landslide and associated soil erosional features. Streams within the number of drainage networks have been the high possibility of landslides incident since the stream wear away the slope bottom with oversupply the submerged part of the slope typing materials (Mersha and Meten, 2020). Because of numerous tributaries within the research area which flows towards Chemoga Rivers, various landslides happened in the close-up surrounding area of the river. Therefore, this constraint was well-thought-out as one underlying factor within landslide susceptibility investigation. Districts through equivalent prototype drainage with sharp slopes were the main credible landslide situates. Drainages frequently play their function in increasing pour water pressures which decrease the shear strengths of slope material. Streamline was produced from Digital Elevation Model and categorized depending on stream order classification. Landslides with this study area were typically related in some sort of stream order. The maps were generated from the Euclidean distance extension buffering technique with the spatial analyst tool of Arc GIS 10.1. These maps were ordered into five sub-classes: 0 - 200, $200-400,400-600,600-800$ and 800-1000 meters showed as below in (Figure. 7).

The final ranks contain a high value of landslides with distance to stream in this orders did not illustrate direct proportion to landslide. The cause for high density of landslide with distance to source order of 800-1000 meter might be united result of additional factor which favored landslide incidence (Getachew and Meten, 2021).

\subsubsection{Lithology}

Lithology is another factor that affects landslides, which is used for susceptibility analysis (El Jazouli et al., 2019). Lithology maps extracted from $1: 500,000$ scales with geology map of Ethiopia explain that the research areas were enclosed into different forms of Lithological components. The component was categorized with five ranks as demonstrated in Figure 8 below.

Lithology is the main preventing constraints with gradient stability hence every rank of materials have distinct shear strength and permeability characters (Yalcin and Bulut, 2007). Various rock forms had different compositions with formations that give to strength of gradient material optimistically otherwise negatively. Stronger rock units provide additional struggle to the driving force as contrasted a softer or weaker rocks. Lithological maps of research areas were organized from the existing regional geological maps since the beginning maps for extra development of lithology maps on level of 1:500000 depend on comprehensive area investigation. Basalt rocks have been high optimistic link to landslide incidence rather sandstone suitable result of conditions since a basalt rock within research areas are extremely affected by weathering, however sandstones have low scale of weathering as the existence of quartz cement (Wubalem, 2021). The study area contains five Lithological units namely Ja (sandstone), P2a (Deeply weathered alkaline and traditional basalt flow with rare intercalations of tuff often tilted), PNtb (Alkaline to traditional basalts often forming shields volcanoes with minor Trachyte and phonolite flows), ARI ( Biotite and hornblende gneisses, granulite and migmatite with negligible metasedimentary gneisses), gt4 (Tectonic granite and syenite) in Table 5 \& Figure 8 illustrated.

Table 5

Percent of the area coverage for lithology in chemoga Watershed

\begin{tabular}{|llll|}
\hline S/N & Lithology & Area(km $\left.{ }^{2}\right)$ & Percent (\%) \\
\hline 1 & Jurassic sandstone & 205.41 & 17.34 \\
\hline 2 & Alkaline and trastional basalt & 306.10 & 25.84 \\
\hline 3 & Alkaline to trastional basalt & 371.64 & 31.37 \\
\hline 4 & Granulite and migmatite & 270.14 & 22.80 \\
\hline 5 & Tectonic granite and syenite & 31.47 & 2.66 \\
\hline
\end{tabular}

\subsubsection{Rainfall}

It is an activating factor for landslide occurrences (Skilodimou et al., 2018). Mean yearly rainfall of watersheds varies between $1050 \mathrm{~mm}$ and 1650 mm. The allocation of envoy rainfall is based upon a spatial allocation of elevation and station (Cristiano et al., 2017). Rainfalls are supposed as weights to basis slope instability. Rainfall mainly concentrated and protracted precipitations were preventing weights that activate landslide by provided that water thus enhancing underground hydrostatics levels as well as pore water pressures. Once soil undertakes as pressure varies, water with it can be produced pessimistic or upward pressure, as it could not exhaust rapidly. While the pore water pressures are comparable to higher pressures, shearing resistance of material reduces as well as would go ahead to breakdown of materials. A data of stations that enclose research areas were gathered from the National Metrology Agency map of Ethiopia. The rainfall map of the research areas was arranged with GIS. The maps of research areas were separated into three annual rainfalls ordered of $900-1200,1200-1500$, and1500 - 1800 millimeters in Figure 6 by the natural breaks method.

\subsubsection{Drainage density factor}


The drainage networks were also generated from $30 \mathrm{~m} \star 30 \mathrm{~m}$ DEM with hydrology tools in ArcGIS 10.1. It is described as proximity of spacing river channel. The whole length of the streams is separated through the entire research region of drainage. Drainages are an inverse function of permeability. As a result, drainage densities are the activating causative weights for landsliding in a chemoga watershed. The smaller amount porous rocks are, the less the penetration of rainfall, which on the other hand tend to be concentrated in surface runoff (Sonker et al., 2021).

It is derivative as of digitized stream methods of chemoga watershed with further rectify with GIS tools. As illustrated in Figure $10 \&$ Table 6 . The landslide susceptibility regions are directly associated with density since their relation with surface runoff and permeability.

Table 6

Percent of the area coverage for drainage density in chemoga Watershed

\begin{tabular}{|lll|}
\hline Drainage density/sq.km & Area(km2) & Percent (\%) \\
\hline $0-0.00079$ & 690.99 & 58.38 \\
\hline $0.00079-0.00184$ & 296.93 & 25.09 \\
\hline $0.00184-0.00185$ & 156.86 & 13.25 \\
\hline $0.00185-0.00245$ & 34.45 & 2.91 \\
\hline $0.00245-0.0184$ & 4.40 & 0.37 \\
\hline
\end{tabular}

\subsection{Multi-criteria evaluation (MCE) technique}

GIS-based Multi-Criteria Evaluation (MCE) approaches are the main significant appliance of figure and spatial analysis of geographic data to sustain the method of environmental decision making. A decision can be defined as giving superiority between alternatives, where the alternatives may be different actions, locations, objects, and the like. The real method of applying the decision rules is called evaluation. To convene exact objectives numerous criteria are required to be assessed. Such procedures are called multi-criteria evaluations (Eastman et al., 1995). Incorporation of multi-criteria evaluation techniques and GIS allow overcoming limitations and supplied a tool with enormous potential for achieved appropriateness or sensitivity maps or choosing locations to fussy movement (Eastman et al., 1995 and Mendoza, 1997). GIS gives a suitable structure for a request of multi-criteria estimation techniques, that are not able to manage spatial data, multi-criteria estimation measures attach to GIS for ways of performing compromises on contradictory objectives, whereas taking into description numerous criterion as well as expert knowledge of decision maker (Carver, 1991). Therefore, the MCE is an efficient tool for numerous criterion decision-making problems. Purposes of multi-criteria evaluations are to examine a numeral of option possibilities within light of numerous criterion with multiple objectives. The incorporation of MCE with GIS (GIS-MCE) can assist landslide susceptibility and environment protection agents and directors to develop decision-making processes. GIS permits the calculation of factors, while multi-criteria evaluations are combined into a sensitivity index.

\subsection{Analytical Hierarchy Process}

AHP is a multi-criteria decision making technique which was initially produced by (Saaty, 1977). AHP was frequent tool for the investigation to maintain site preference, urban planning, and natural risk susceptibility examination (Meena et al., 2019). AHP is decision making procedure that depends on multi-criteria with numerous objectives as well as occupies contribution of professionals (Saaty and Vargas, 1984). Level of sort of factors and statistical values are generated depend on the significance of each weight (Ghorbanzadeh et al., 2019). The AHP was applied to produces a correlative pair-wise contrast matrix. This matrix is created with values that symbolize professional decisions with contrasting the significance of each weight relative to all the other associated weights (Meena et al., 2019). The data is obtained from definite measurements like value, factors, or biased attitudes like contentment feelings and preference. AHP permit some small inconsistency within decision since human is not for all time reliable. The proportion scales are generated from the main eigenvector plus reliability index is derivative from the foremost Eigen value (Shiferaw, 2020). AHP has been concerned the interest of many researchers mostly due to the good numerical characteristics of technique and reality that necessary input data are fairly easy to acquire. Its primary utilize to offer a solution to decision troubles in multivariate environments, in which numerous options for acquired known objectives are under dissimilar criteria. The Analytical Hierarchy Process creates decision weights for options by arranging objectives, criteria, and subcriteria in a level formation. Analytical Hierarchy Process is an influential and bendable decision-making process to assist people to put priority and construct most excellent decisions as both qualitative as well as quantitative features of decision require to be measured. Both qualitative and quantitative information could be contrasted with informed decisions to derive weights and main concerns. All layers depend on nine point ranking level and are added to matrix as produced in Table 7 below by (Saaty, 1977). The judgment maker identifies the rates of all weights. The factors as of matrix rank were multiply by weight ranks. Local illustration of factors within a research areas estimated consequences of susceptibility maps. The factor was biased with pair-wise evaluation matrices of AHP depend on professional knowledge's (Meena et al., 2019).

AHP is a universal trouble answering technique that was helpful with designing complex decisions depend on variables that did not have accurate mathematical results. The main benefits of AHP are that investigation did not constantly necessitate statistically important model size. The ease of the Analytical Hierarchy Process moves towards that, different additional conjoint techniques, qualities of various features are not directly evaluated. AHP approach eliminates difficult inspection plans and can even be used with only a single respondent. Analytical Hierarchy Processes are practical approaches that might be used to determine extremely difficult decision-making troubles concerning numerous scenarios weights or factors. 
As a result, AHP was essential to calculate the reliability of professional comparison with matrix in all periods (Hasekioğulları and Ercanoglu, 2012). Inconsistency could be described depending on inspection which is $\lambda_{\max }>\mathrm{n}$, used for comparison matrix and $\lambda_{\max }=\mathrm{n}$ if $\mathrm{C}$ is a reliable comparison. $\mathrm{A}$ consistency ratio (CR) is described in Equation (1) :

$\mathrm{CR}=\left(\lambda_{\max }-\mathrm{n}\right) /(\mathrm{RI}(\mathrm{n}-1))$

Where; RI is a random index of arbitrarily formed pair wise comparison matrix for $n=1,2,3,4,5,6,7,8$ and 9 . If $C R<10 \%$ it shows as an acceptable level of reliability. Were: CR > 10\% values to a degree of inconsistency (Saaty, 1980).

Table 7

Saaty's Rating Scale

\begin{tabular}{|c|c|c|}
\hline $\begin{array}{l}\text { Intensity of } \\
\text { importance }\end{array}$ & Description & justification \\
\hline 1 & the same significance & Two actions provide uniformly to the goal \\
\hline 3 & $\begin{array}{l}\text { fragile significance one over } \\
\text { another }\end{array}$ & knowledge with decision somewhat support single movement over another \\
\hline 5 & $\begin{array}{l}\text { critical otherwise burly } \\
\text { significance }\end{array}$ & knowledge with decision powerfully support single movement over another \\
\hline 7 & Demonstrated significance & $\begin{array}{l}\text { verified significance movement powerfully privileged with control verified within } \\
\text { carrying out }\end{array}$ \\
\hline 9 & Absolute additional significance & $\begin{array}{l}\text { facts support single movement over another is maximum probable order of } \\
\text { declaration }\end{array}$ \\
\hline $2,4,6,8$ & $\begin{array}{l}\text { transitional values among two } \\
\text { neighboring decisions }\end{array}$ & once a compromise is desirable \\
\hline
\end{tabular}

Table 8

Arbitrary Inconsistency Indexes

\begin{tabular}{|lllllllllll|}
\hline $\mathbf{n}$ & $\mathbf{1}$ & $\mathbf{2}$ & $\mathbf{3}$ & $\mathbf{4}$ & $\mathbf{5}$ & $\mathbf{6}$ & $\mathbf{7}$ & $\mathbf{8}$ & $\mathbf{9}$ & $\mathbf{1 0}$ \\
$\mathrm{RI}$ & 0.00 & 0.00 & 0.58 & 0.90 & 1.12 & 1.24 & 1.32 & 1.41 & 1.45 & 1.49 \\
\hline
\end{tabular}

\subsection{Weighting and pair-wise comparison}

Scales are one-to-one mapping among the set of different options obtainable to the expert knowledge with a distinct set of figures which symbolize the significance, or else weights of earlier linguistics option, which enables to quantify pair wise evaluation. Rates of pair wise evaluations with analytic hierarchy process are resolved according to the level established by (Saaty, 1980). The purpose of weighting in soil erosion source area identification is to determine the significance of each factor with additional factors that affect the rate of soil erosion. The weights should be cleared with analytic hierarchy process (AHP) module within ArcMap. AHP is an incredibly fashionable way to compute the desired weighting factors with the assist of a predilection matrix whereas all recognized applicable factors are evaluated against each other with reproducible predilection weights. The weighting overlays are an easy, straight plus sufficient tool obtainable within GIS environment which is applied broadly resolve multi criteria troubles, for instance, landslide susceptibility (Senouci et al., 2021). This technique including a combination of various factors considering its specified weights (Kaur et al., 2018). In this research, class rates and factor weights had been calculated with the analytic hierarchy processes. To construct a forecasting landslide susceptibility maps, all constraints were incorporated within Weighting overlay method in GIS environments. Sum of weights have equivalent to 100 . For that reason, all Criteria weights are multiply by its allocated factors along with the following equation (2).

$\mathrm{LSM}=\sum(X i * W i)$

Where; $X_{i}$ is the level of each rank and $W_{i}$ is the weights of the calculating factors.

\section{Result And Discussion}

\subsection{Landslide Susceptibility factors analysis}

The major Landslide Susceptibility contributing factors such as elevation, slope, aspect, soil type, lithology, distance to stream, land use land cover, rainfall as well as drainage density had been applied for landslide susceptibility identification. The raster values were categorized depending on the susceptibility capability of the Chemoga watershed (Desalegn and Mulu, 2021). All the factors were categorized and weighted depending on their significance. Numerical scales one to five from very low to very high weighted factors were used. The main weighted factors were: lithology, slope, land cover, and aspect. Curvature plain, rainfall, distance to stream, and distance to roads were equally significant with an approach to slope instability(Senouci et al., 2021). For this research, the factors classified from very low to very high weighting were used. The main prominent factors were elevation, slope, aspect, and soil type concerning multi criteria decision making technique a pair-wise comparison of six criteria for AHP process. To 
produce landslide susceptibility map the sum of all weight multiplied by its influencing weight was carried out in the raster calculator tools by making an allowance for the above equation (2).

The slope classification $>12^{0}$ has been higher input for landslide incidence. The slope classes $>45^{0}$ are the highest landslide level classes whereas the slope classes $<5^{0}$ are the smallest ones (Mersha and Meten, 2020). For this research, the less significant slope values were level landscape with similarly, the higher slope values were sharp landscape. Based on their susceptibility to landsliding, slopes were classified into five classes. $0-5^{0}, 5-11^{0}$, $11-19^{0}, 19-29^{0}$ and $29-59^{0}$. Generally, since the gradient raising, the possibility of landslide incidence as well increases. The other factor was aspect ranks, values of gradient ranks facing near to northeast (22.5-67.5), east (67.5-112.5) with north (0-22.5) were larger than one indicative of advanced possibility of landslide happening. The northeast-facing aspect ranks have gotten the utmost influence otherwise ranking pursued with the east-facing ones (Mersha and Meten, 2020). The chemoga watershed aspect ranks are the values of slope ranks facing near the flat $(-1)$, north $\left(0^{0}-22.5^{0}\right)$, northeast $\left(22.5^{0}-67.5^{0}\right)$, east $\left(67.5^{0}-112.5^{0}\right)$, south-east $\left(112.5^{0}-157.5^{0}\right)$, south $\left(157.5^{0}-202.5^{0}\right)$, south-west $\left(202.5^{0}-247.5^{0}\right)$,west $\left(247.5^{0}-292.5^{0}\right)$,north-west $\left(292.5^{0}\right.$ $\left.337.5^{0}\right)$, with north $\left(337.5^{0}-360^{0}\right)$.

In the case of lithology, five components i.e. Ja (sandstone), P2a (Deeply weathered alkaline as well as traditional basalts flows through rare intercalations of tuff often tilted), PNtb (Alkaline to traditional basalts often forming shields volcanoes with minor Trachyte and phonolite flows), ARI (Biotite and hornblende gneisses, granulite and migmatite with minor metasedimentary gneisses), gt4 (Tectonic granite and syenite) have a high possibility of landslide incidence. Ja, P2a and PNtb basalt have been less strong and for this reason susceptible to landslides. The form of land use land cover can be ordered the incident of landslide in the chemoga watershed areas. Land use land cover of chemoga watershed areas was reclassified within nine frequent ranks and was enhanced into the raster layer. The highest weights were examined within the land-use class of grassland, cultivation land, bare land, plantation, wetland, and shrub land indicative of a high possibility of landslide incidence. The correlation among landslide incidence and distance from the river, since distance from river raise, the happening of landslide normally reduces (Mersha and Meten, 2020). In the case of the chemo watershed study, distance from stream land sliding factors, when the distance from stream increase, the incidence of landslide to reduce. Landslide incidence was higher with the following ordered classification of 0-200m, 200-400 m, 400-600m, 600-800m and 800-1000m. As considered to the contributory landslide factors of rainfall, can be classified rainfalls were provided into three classes value, influence with resulting very high landslide value was the least valuable one, viewing amazingly low effect insignificant very low land sliding rate. Consequently, the area with extremely high rainfalls is showed to the classification, $900-1200,1200-1500$, and1500 - $1800 \mathrm{~mm}$ and the study area has been extremely low rainfalls are ranked to class one, as illustrated in the list based on their high value.

The study areas were applied to calculate a drainage density through spatial analyst tool. Depending on a categorization technique, the one that has higher values are extremely affected with landslide and ranked to five $(>0.0184 / \mathrm{km})$ with area coverage of $0.37 \%$, high ranks to four $(0.00245-0.0184$ $/ \mathrm{km})$ with area coverage of $2.91 \%$, moderate ranks to three $(0.00185-0.00245 / \mathrm{km})$ with area coverage of $13.25 \%$, low ranked to two $(0.00184-0.00185$ $/ \mathrm{km})$ with area coverage of $25.09 \%$ and extremely low ranked to one $(<0.00079 / \mathrm{km})$ with area coverage of $58.38 \%$.

\subsection{Analytical Hierarchy Process and Weighting overlay}

Analytical Hierarchy Process was applied to estimate the weighting overlay and ratings for class influential weights: elevation, slope, aspect, Soil type, Lithology, Distance to stream, Land use land cover, rainfall and drainage density were obtained from pair-wise comparison matrix. The matrix was applied to the class rating of each constraint and to calculated the Criteria weight value in excel software. As showed in Table 4, elevation was the most influential value factor, with a value of 0.27 . The slope also has been the significant value of 0.18 , followed by aspect value which was 0.16 , soil type which was 0.12 , and lithology which was 0.08 the rest ones were listed in Table 4.

Table 9

A matrix of pairwise comparisons of six criteria for the AHP process

\begin{tabular}{|c|c|c|c|c|c|c|c|c|c|}
\hline & Elevation & Slope & Aspect & $\begin{array}{l}\text { Soil } \\
\text { type }\end{array}$ & Lithology & $\begin{array}{l}\text { Distance to } \\
\text { stream }\end{array}$ & $\begin{array}{l}\text { Land } \\
\text { use/cover }\end{array}$ & Rainfall & $\begin{array}{l}\text { Drainage } \\
\text { density }\end{array}$ \\
\hline Elevation & 1 & 5 & 5 & 3 & 3 & 5 & 3 & 5 & 3 \\
\hline Slope & $1 / 5$ & 1 & 3 & 3 & 5 & 3 & 5 & 5 & 3 \\
\hline Aspect & $1 / 5$ & $1 / 3$ & 1 & 3 & 5 & 5 & 3 & 5 & 5 \\
\hline Soil type & $1 / 3$ & $1 / 3$ & $1 / 3$ & 1 & 3 & 5 & 3 & 5 & 5 \\
\hline Lithology & $1 / 3$ & $1 / 5$ & $1 / 5$ & $1 / 3$ & 1 & 3 & 3 & 5 & 3 \\
\hline Distance to stream & $1 / 5$ & $1 / 3$ & $1 / 5$ & $1 / 5$ & $1 / 3$ & 1 & 3 & 3 & 3 \\
\hline $\begin{array}{l}\text { Land use land } \\
\text { cover }\end{array}$ & $1 / 3$ & $1 / 5$ & $1 / 3$ & $1 / 3$ & $1 / 3$ & $1 / 3$ & 1 & 3 & 5 \\
\hline Rainfall & $1 / 5$ & $1 / 5$ & $1 / 5$ & $1 / 5$ & $1 / 5$ & $1 / 3$ & $1 / 3$ & 1 & 3 \\
\hline Drainage density & $1 / 3$ & $1 / 3$ & $1 / 5$ & $1 / 5$ & $1 / 3$ & $1 / 3$ & $1 / 5$ & $1 / 3$ & 1 \\
\hline
\end{tabular}


Table 10

Pair-wise comparison decimal matrix

\begin{tabular}{|c|c|c|c|c|c|c|c|c|c|}
\hline & Elevation & Slope & Aspect & $\begin{array}{l}\text { Soil } \\
\text { type }\end{array}$ & Lithology & $\begin{array}{l}\text { Distance to } \\
\text { stream }\end{array}$ & $\begin{array}{l}\text { Land } \\
\text { use/cover }\end{array}$ & Rainfall & $\begin{array}{l}\text { Drainage } \\
\text { density }\end{array}$ \\
\hline Elevation & 1 & 5 & 5 & 3 & 3 & 5 & 3 & 5 & 3 \\
\hline Slope & 0.2 & 1 & 3 & 3 & 5 & 3 & 5 & 5 & 3 \\
\hline Aspect & 0.2 & 0.33 & 1 & 3 & 5 & 5 & 3 & 5 & 5 \\
\hline Soil type & 0.33 & 0.33 & 0.33 & 1 & 3 & 5 & 3 & 5 & 5 \\
\hline Lithology & 0.33 & 0.2 & 0.2 & 0.33 & 1 & 3 & 3 & 5 & 3 \\
\hline Distance to stream & 0.2 & 0.33 & 0.2 & 0.2 & 0.33 & 1 & 3 & 3 & 3 \\
\hline $\begin{array}{l}\text { Land use land } \\
\text { cover }\end{array}$ & 0.33 & 0.2 & 0.33 & 0.33 & 0.33 & 0.33 & 1 & 3 & 5 \\
\hline Rainfall & 0.2 & 0.2 & 0.2 & 0.2 & 0.2 & 0.33 & 0.33 & 1 & 3 \\
\hline Drainage density & 0.33 & 0.33 & 0.2 & 0.2 & 0.33 & 0.33 & 0.2 & 0.33 & 1 \\
\hline Sum & 3.12 & 7.92 & 10.46 & 11.26 & 19.19 & 22.99 & 21.53 & 32.33 & 31 \\
\hline
\end{tabular}

Table 11

Normalized pair-wise matrix calculated

\begin{tabular}{|c|c|c|c|c|c|c|c|c|c|}
\hline & Elevation & Slope & Aspect & $\begin{array}{l}\text { Soil } \\
\text { type }\end{array}$ & Lithology & $\begin{array}{l}\text { Distance to } \\
\text { stream }\end{array}$ & $\begin{array}{l}\text { Land } \\
\text { use/cover }\end{array}$ & Rainfall & $\begin{array}{l}\text { Drainage } \\
\text { density }\end{array}$ \\
\hline Elevation & 0.32 & 0.63 & 0.48 & 0.27 & 0.16 & 0.22 & 0.14 & 0.15 & 0.10 \\
\hline Slope & 0.06 & 0.13 & 0.29 & 0.27 & 0.26 & 0.13 & 0.23 & 0.15 & 0.10 \\
\hline Aspect & 0.06 & 0.04 & 0.10 & 0.27 & 0.26 & 0.22 & 0.14 & 0.15 & 0.16 \\
\hline Soil type & 0.11 & 0.04 & 0.03 & 0.09 & 0.16 & 0.22 & 0.14 & 0.15 & 0.16 \\
\hline Lithology & 0.11 & 0.03 & 0.02 & 0.03 & 0.05 & 0.13 & 0.14 & 0.15 & 0.10 \\
\hline Distance to stream & 0.06 & 0.04 & 0.02 & 0.02 & 0.02 & 0.04 & 0.14 & 0.09 & 0.10 \\
\hline $\begin{array}{l}\text { Land use land } \\
\text { cover }\end{array}$ & 0.11 & 0.03 & 0.03 & 0.03 & 0.02 & 0.01 & 0.05 & 0.09 & 0.16 \\
\hline Rainfall & 0.06 & 0.03 & 0.02 & 0.02 & 0.01 & 0.01 & 0.02 & 0.03 & 0.10 \\
\hline Drainage density & 0.11 & 0.04 & 0.02 & 0.02 & 0.02 & 0.01 & 0.01 & 0.01 & 0.03 \\
\hline
\end{tabular}

Table 12

Determined relative criterion weights

\begin{tabular}{|c|c|c|c|c|c|c|c|c|c|c|}
\hline & Elevation & Slope & Aspect & $\begin{array}{l}\text { Soil } \\
\text { type }\end{array}$ & Lithology & $\begin{array}{l}\text { Distance to } \\
\text { stream }\end{array}$ & $\begin{array}{l}\text { Land use/ } \\
\text { cover }\end{array}$ & Rainfall & $\begin{array}{l}\text { Drainage } \\
\text { density }\end{array}$ & Weighted \\
\hline Elevation & 0.32 & 0.63 & 0.48 & 0.27 & 0.16 & 0.22 & 0.14 & 0.15 & 0.10 & 0.27 \\
\hline Slope & 0.06 & 0.13 & 0.29 & 0.27 & 0.26 & 0.13 & 0.23 & 0.15 & 0.10 & 0.18 \\
\hline Aspect & 0.06 & 0.04 & 0.10 & 0.27 & 0.26 & 0.22 & 0.14 & 0.15 & 0.16 & 0.16 \\
\hline Soil type & 0.11 & 0.04 & 0.03 & 0.09 & 0.16 & 0.22 & 0.14 & 0.15 & 0.16 & 0.12 \\
\hline Lithology & 0.11 & 0.03 & 0.02 & 0.03 & 0.05 & 0.13 & 0.14 & 0.15 & 0.10 & 0.08 \\
\hline $\begin{array}{l}\text { Distance to } \\
\text { stream }\end{array}$ & 0.06 & 0.04 & 0.02 & 0.02 & 0.02 & 0.04 & 0.14 & 0.09 & 0.10 & 0.06 \\
\hline $\begin{array}{l}\text { Land use land } \\
\text { cover }\end{array}$ & 0.11 & 0.03 & 0.03 & 0.03 & 0.02 & 0.01 & 0.05 & 0.09 & 0.16 & 0.06 \\
\hline Rainfall & 0.06 & 0.03 & 0.02 & 0.02 & 0.01 & 0.01 & 0.02 & 0.03 & 0.10 & 0.04 \\
\hline Drainage density & 0.11 & 0.04 & 0.02 & 0.02 & 0.02 & 0.01 & 0.01 & 0.01 & 0.03 & 0.03 \\
\hline
\end{tabular}


Table 13

The weights of all landslide factors

\begin{tabular}{|ll|}
\hline \multicolumn{2}{|c|}{ value } \\
\hline Landsliding Factor & Weighted (\%) \\
\hline Elevation & 27 \\
\hline Slope & 18 \\
\hline Aspect & 16 \\
\hline Soil type & 12 \\
\hline Lithology & 8 \\
\hline Distance to stream & 6 \\
\hline Land use land cover & 6 \\
\hline Rainfall & 4 \\
\hline Drainage density & 3 \\
\hline
\end{tabular}

Table 14

Determined Consistency Ratio (CR)

\begin{tabular}{|c|c|c|c|c|c|c|c|c|c|c|c|c|}
\hline & Elevation & Slope & Aspect & $\begin{array}{l}\text { Soil } \\
\text { type }\end{array}$ & Lithology & $\begin{array}{l}\text { Distance } \\
\text { to } \\
\text { stream }\end{array}$ & $\begin{array}{l}\text { Land } \\
\text { use/ } \\
\text { cover }\end{array}$ & Rainfall & $\begin{array}{l}\text { Drainage } \\
\text { density }\end{array}$ & $\begin{array}{l}\text { Weights } \\
\text { sum }\end{array}$ & Weighted & $\begin{array}{l}\text { Weights } \\
\text { sum/weighted }\end{array}$ \\
\hline Elevation & 0.27 & 0.90 & 0.80 & 0.36 & 0.24 & 0.30 & 0.18 & 0.20 & 0.09 & 3.34 & 0.27 & 12.37 \\
\hline Slope & 0.05 & 0.18 & 0.48 & 0.36 & 0.40 & 0.18 & 0.30 & 0.20 & 0.09 & 2.24 & 0.18 & 12.44 \\
\hline Aspect & 0.05 & 0.06 & 0.16 & 0.36 & 0.40 & 0.30 & 0.18 & 0.20 & 0.15 & 1.86 & 0.16 & 11.62 \\
\hline Soil type & 0.09 & 0.06 & 0.05 & 0.12 & 0.24 & 0.30 & 0.18 & 0.20 & 0.15 & 1.39 & 0.12 & 11.58 \\
\hline Lithology & 0.09 & 0.04 & 0.03 & 0.04 & 0.08 & 0.18 & 0.18 & 0.20 & 0.09 & 0.39 & 0.08 & 4.87 \\
\hline $\begin{array}{l}\text { Distance } \\
\text { to } \\
\text { stream }\end{array}$ & 0.05 & 0.06 & 0.03 & 0.02 & 0.03 & 0.06 & 0.18 & 0.12 & 0.09 & 0.64 & 0.06 & 10.66 \\
\hline $\begin{array}{l}\text { Land use } \\
\text { land } \\
\text { cover }\end{array}$ & 0.09 & 0.04 & 0.05 & 0.04 & 0.03 & 0.02 & 0.06 & 0.12 & 0.15 & 0.6 & 0.06 & 10 \\
\hline Rainfall & 0.05 & 0.04 & 0.02 & 0.02 & 0.02 & 0.02 & 0.02 & 0.04 & 0.09 & 0.32 & 0.04 & 8 \\
\hline $\begin{array}{l}\text { Drainage } \\
\text { density }\end{array}$ & 0.09 & 0.06 & 0.03 & 0.02 & 0.03 & 0.02 & 0.01 & 0.01 & 0.03 & 0.30 & 0.03 & 10 \\
\hline
\end{tabular}

The $R /$ within grouping by $\lambda_{\max }$ is applied for calculation of Consistency Index and calculates values if $<10 \%$ found judgments are reliable. Within this research area, an effort had been completed to recognize the landslide area of Chemoga watershed using nine spatially distributed landslide hazard parameter factors like elevation, slope, aspect, soil type, lithology, distance to stream, land use land cover, rainfall, as well as drainage density in Saaty's AHP based MCDA support tools. The influence gets hold of from Saaty's AHP analysis was applied to obtain ultimate priority of Chemoga watersheds. The reliability of personal decisions could be verified with an approximate reliability ratio that is evaluation among consistency index and random consistency index. The consistency index (CR) has been calculated the following equation: The Consistency Index (Cl) can be determined of exit from reliability, was determined with the formula:

$\mathrm{Cl}=\frac{\lambda-n}{n-1}$

Where; $\boldsymbol{n}$ is the number of factors (i.e. 9 ) and $\boldsymbol{\lambda}$ is the mean value of the reliability vector find out in the above Table (14).

$\lambda=(12.37+12.44+11.62+11.58+4.87+10.66+10+8+10) / 9=10$

Depend on the above equation, $\mathrm{Cl}=10-9 / 9-1=0.13$

To evaluate the strength of the author's outlook the consistency ratios (CR) were calculated with equation (1). Where, RI is random inconsistency index values based on number $(n)$ of factors being balanced; for $n=9, R I=1.45$ as showed in Table 8 above.

$$
C R=\frac{0.13}{1.45}=0.09
$$

As a result, $0.09<0.1$, this value point out there was a pragmatic degree of reliability within the pair wise comparison and therefore, the criteria weight values were $0.27,0.18,0.16,0.12,0.08,0.06,0.06,0.04$, and 0.03 had been allocated to Elevation, Slope, Aspect, Soil type, Lithology, Distance to stream, 
Land use land cover, Rainfall and Drainage density respectively.

\subsection{Landslide Susceptibility Maps}

In the chemoga watershed research areas were used, GIS-based Analytical Hierarchy Process as multi-criteria analysis approach to mapping the prospective landslide incidences. The analytical hierarchy process model was predictably dependent on the ranking classification afforded with expert judgment. The expert outlook was incredibly helpful within determine difficult harms seems like landslide incidence. Depend on landslide susceptibility maps results were categorized into five ranks: very low, low, moderate, high and very high as showed in Figure 12 below. A very low area susceptible to landsliding coverage was $550.61 \mathrm{~km}^{2}(46.52 \%)$, low areas susceptible to landsliding coverage was $163.72 \mathrm{~km}^{2}(13.83 \%)$, moderate areas susceptible to landsliding coverage was $221.51 \mathrm{~km}^{2}(18.71 \%)$, high areas susceptible to landsliding coverage was $182.15 \mathrm{~km}^{2}(15.39 \%)$, very high areas susceptible to landsliding coverage was $65.64 \mathrm{~km}^{2}(5.55 \%)$ of the total chemoga watershed research area in Figure12 \& Table 15.

Table 15

Chemoga watershed area of landslide susceptibility map ranks

\begin{tabular}{|lll|}
\hline Landsliding susceptibility ranks & Area in $\left(\mathbf{k m}^{2}\right)$ & Area in (\%) \\
\hline Very Low & 550.61 & 46.52 \\
\hline Low & 163.72 & 13.83 \\
\hline Moderate & 221.51 & 18.71 \\
\hline High & 182.15 & 15.39 \\
\hline Very High & 65.64 & 5.55 \\
\hline
\end{tabular}

\subsection{Validation of the model}

A final landslide susceptibility map of the chemoga watershed should be validated. Without model validation, the susceptibility map does not give significance (Mersha and Meten, 2020). A predictive model map was constructed by using ArcSDM with the extension of ArcGIS tools to generate AUC and overlying of the landslides with GPS field data and Google earth data over the causative factor. Depend on Area under curve calculation (AUC) a value of AUC were classified regarding 0.9-1.0 ranks as test quality was excellent, 0.8- 0.9 ranks as test quality was very good, 0.7- 0.8 ranks as test quality was good, 0.6- 0.7 ranks as test quality was satisfactory, 0.5- 0.6 unsatisfactory, under this criteria, since the spatial efficiency of the produced landslide susceptibility maps verified with AUC (76.7\% of accuracy), which was observed that applied model capitulated a good outcome for landsliding susceptibility maps within research areas (El Jazouli et al., 2019). As a result, chemoga watershed landslide susceptibility map result showed very good accuracy of AUC value $81.45 \%$.

\section{Conclusions}

The landslide is a crucial natural event, hence identification of areas at the hazard of landslide and mapping of the landslide susceptibilities were the significance of the chemoga watershed for researchers, governmental organizations, and non-governmental organizations. Landsliding vulnerability research has been done in the incident of the causative factors for landsliding using, GIS and analytical hierarchy process technique as a multi-criteria analysis approach, which authorizes the study of landslide to depend on the existence of the selection factors and manipulation, investigation of required environmental data for landslide susceptibility maps. Within this research, landslide factors of watershed consist of elevation, slope, aspect, soil type, lithology, distance to stream, land use land cover, rainfall as well as drainage density were evaluated. Landslide susceptibility map was categorized with the natural break system into five ranks with, very low areas susceptible to landsliding $550.61 \mathrm{~km}^{2}(46.52 \%)$, low areas susceptible to landsliding $163.72 \mathrm{~km}^{2}$ (13.83\%), moderate areas susceptible to landsliding $221.51 \mathrm{~km}^{2}(18.71 \%)$, high areas susceptible to landsliding $182.15 \mathrm{~km}^{2}(15.39 \%)$, very high areas susceptible to landsliding $65.64 \mathrm{~km}^{2}(5.55 \%)$ of the total chemoga watershed research area. The model was validated; the result showed that the AUC value of $81.45 \%$ was a very good accuracy classification of test quality. Furthermore, the landsliding susceptibility map of the chemoga watershed supplies further information about current and future landslide, which makes it feasible. The chemoga watershed landslide map might be supportive for the accountable person of the regions and the regions have to collaborate to preserve landslide susceptibility zone and have to plan landslide threats, analysis plan on their development plan with decision makers for land use land cover scheduling and gradient managing within research areas to afford preservation of landslide hazards and to take defensive with appropriate precaution actions. Improvement of landsliding defense constructions with soil protection practice must be performed within landslide areas of place to reduce the magnitude of landslides.

\section{References}

1. Aghdam IN, Varzandeh MHM and Pradhan B. (2016) Landslide susceptibility mapping using an ensemble statistical index (Wi) and adaptive neurofuzzy inference system (ANFIS) model at Alborz Mountains (Iran). Environmental Earth Sciences 75: 1-20.

2. Chen L, Guo Z, Yin K, et al. (2019) The influence of land use and land cover change on landslide susceptibility: a case study in Zhushan Town, Xuan'en County (Hubei, China). Natural hazards and earth system sciences 19: 2207-2228. 
3. Chen W, Xie X, Wang J, et al. (2017) A comparative study of logistic model tree, random forest, and classification and regression tree models for spatial prediction of landslide susceptibility. Catena 151: 147-160.

4. Conforti M, Pascale S, Robustelli G, et al. (2014) Evaluation of prediction capability of the artificial neural networks for mapping landslide susceptibility in the Turbolo River catchment (northern Calabria, Italy). Catena 113: 236-250.

5. Cristiano E, Veldhuis M-Ct and Giesen Nvd. (2017) Spatial and temporal variability of rainfall and their effects on hydrological response in urban areas-a review. Hydrology and Earth System Sciences 21: 3859-3878.

6. Desalegn H and Mulu A. (2021) Flood vulnerability assessment using GIS at Fetam watershed, upper Abbay basin, Ethiopia. Heliyon 7: e05865.

7. Dou J, Tien Bui D, P. Yunus A, et al. (2015) Optimization of causative factors for landslide susceptibility evaluation using remote sensing and GIS data in parts of Niigata, Japan. PloS one 10: e0133262.

8. El Jazouli A, Barakat A and Khellouk R. (2019) GIS-multicriteria evaluation using AHP for landslide susceptibility mapping in Oum Er Rbia high basin (Morocco). Geoenvironmental Disasters 6: 1-12.

9. Gbadebo A, Adedeji O and Edogbo A. (2018) GIS-based landslide susceptibility assessment in Eyinoke Hilly Area of Okeigbo, SW, Nigeria. Journal of Applied Sciences and Environmental Management 22: 917-924.

10. Getachew N and Meten M. (2021) Weights of evidence modeling for landslide susceptibility mapping of Kabi-Gebro locality, Gundomeskel area, Central Ethiopia. Geoenvironmental Disasters 8: 1-22.

11. Ghorbanzadeh O, Moslem S, Blaschke T, et al. (2019) Sustainable urban transport planning considering different stakeholder groups by an intervalAHP decision support model. Sustainability 11: 9.

12. Hasekioğulları GD and Ercanoglu M. (2012) A new approach to use AHP in landslide susceptibility mapping: a case study at Yenice (Karabuk, NW Turkey). Natural Hazards 63: 1157-1179.

13. Kalantar B, Pradhan B, Naghibi SA, et al. (2018) Assessment of the effects of training data selection on the landslide susceptibility mapping: a comparison between support vector machine (SVM), logistic regression (LR) and artificial neural networks (ANN). Geomatics, Natural Hazards and Risk 9: 49-69.

14. Kaur H, Gupta S, Parkash S, et al. (2018) Knowledge-driven method: A tool for landslide susceptibility zonation (LSZ). Geology, Ecology, and Landscapes: 1-15.

15. Kıncal C, Li Z, Drummond J, et al. (2017) Landslide Susceptibility Mapping Using GIS-based Vector Grid File (VGF) Validating with InSAR Techniques: Three Gorges, Yangtze River (China). AIMS Geosciences 3: 116-141.

16. Lee M, Park I, Won J, et al. (2016) Landslide hazard mapping considering rainfall probability in Inje, Korea. Geomatics, Natural Hazards and Risk 7: 424-446.

17. Lee S and Park I. (2013) Application of decision tree model for the ground subsidence hazard mapping near abandoned underground coal mines. Journal of environmental management 127: 166-176.

18. Meena SR, Ghorbanzadeh $O$ and Blaschke T. (2019) A comparative study of statistics-based landslide susceptibility models: A case study of the region affected by the gorkha earthquake in nepal. ISPRS international journal of geo-information 8: 94.

19. Mersha T and Meten M. (2020) GIS-based landslide susceptibility mapping and assessment using bivariate statistical methods in Simada area, northwestern Ethiopia. Geoenvironmental Disasters 7: 1-22.

20. Noorollahi Y, Sadeghi S, Yousefi H, et al. (2018) Landslide modelling and susceptibility mapping using AHP and fuzzy approaches. Int J Hydro 2 : 137-148.

21. Noviyanto A, Sartohadi J and Purwanto BH. (2020) The distribution of soil morphological characteristics for landslide-impacted Sumbing Volcano, Central Java-Indonesia. Geoenvironmental Disasters 7: 1-19.

22. Ntelis G, Maria S and Efthymios L. (2019) Landslide Susceptibility Estimation Using GIS. Evritania Prefecture: A Case Study in Greece. Journal of Geoscience and Environment Protection 7: 206-220.

23. Oh H-J, Lee S and Hong S-M. (2017) Landslide susceptibility assessment using frequency ratio technique with iterative random sampling. Journal of Sensors 2017.

24. Pradhan B. (2013) A comparative study on the predictive ability of the decision tree, support vector machine and neuro-fuzzy models in landslide susceptibility mapping using GIS. Computers \& Geosciences 51: 350-365.

25. Rabby YW, Ishtiaque A and Rahman M. (2020) Evaluating the effects of digital elevation models in landslide susceptibility mapping in rangamati district, bangladesh. Remote Sensing 12: 2718.

26. Reichenbach P, Busca, C., Mondini, AC, Rossi, M., 2014. (2014) Busca, C., Mondini, AC, Rossi, M., 2014. The influence of land use change on landslide susceptibility zonation: the Briga catchment test site (Messina, Italy): 1372-1384.

27. Saaty T. (1980) The Analytical Hierarchy Process McGraw-Hill. New York.

28. Saaty TL. (1977) A scaling method for priorities in hierarchical structures. Journal of Mathematical Psychology 15: $234-281$.

29. Saaty TL and Vargas LG. (1984) Inconsistency and rank preservation. Journal of Mathematical Psychology 28: 205-214.

30. Senouci R, Taibi N-E, Teodoro AC, et al. (2021) GIS-based expert knowledge for landslide susceptibility mapping (LSM): case of Mostaganem Coast District, West of Algeria. Sustainability 13: 630. 
31. Shiferaw G. (2020) Soil loss estimation and source areas using rusle and mce technique in chemoga watershed, blue nile basin.

32. Skilodimou HD, Bathrellos GD, Koskeridou E, et al. (2018) Physical and anthropogenic factors related to landslide activity in the Northern Peloponnese, Greece. Land 7: 85.

33. Sonker I, Tripathi JN and Singh AK. (2021) Landslide susceptibility zonation using geospatial technique and analytical hierarchy process in Sikkim Himalaya. Quaternary Science Advances 4: 100039.

34. Wahono BFD. (2010) Applications of statistical and heuristic methods for landslide susceptibility assessments. Unpublished Technical Report. Gadjah Mada University and International Institute for Geo-Information Science and Earth Observation.

35. Wang Q, Li W, Chen W, et al. (2015) GIS-based assessment of landslide susceptibility using certainty factor and index of entropy models for the Qianyang County of Baoji city, China. Journal of Earth System Science 124: 1399-1415.

36. Wubalem A. (2021) Landslide susceptibility mapping using statistical methods in Uatzau catchment area, northwestern Ethiopia. Geoenvironmental Disasters 8: 1-21.

37. Yalcin A, Reis S, Aydinoglu A, et al. (2011) A GIS-based comparative study of frequency ratio, analytical hierarchy process, bivariate statistics and logistics regression methods for landslide susceptibility mapping in Trabzon, NE Turkey. Catena 85: 274-287.

\section{Figures}

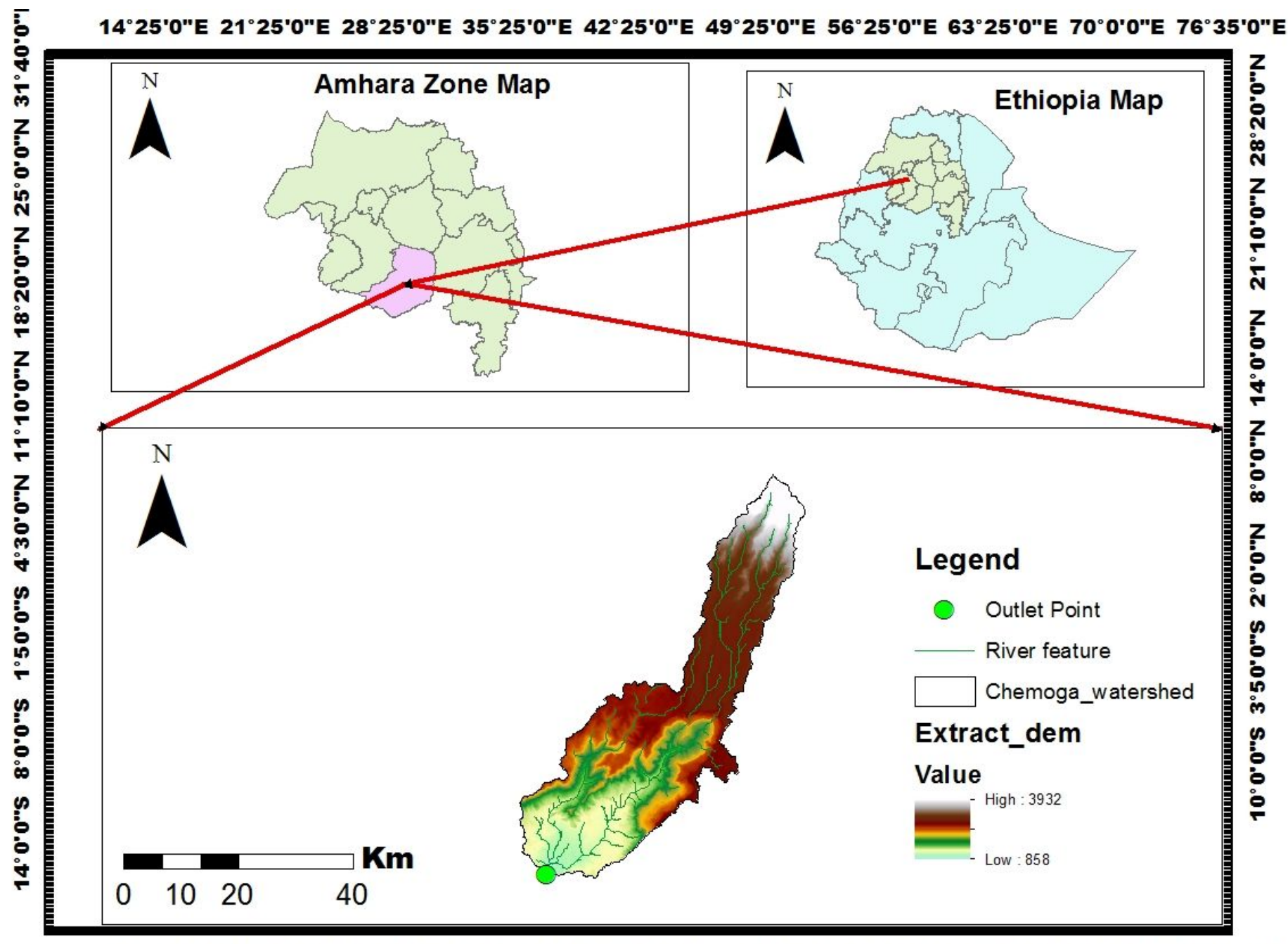

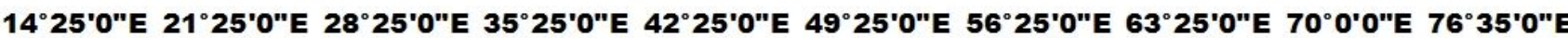

Figure 1

Location maps of research area 


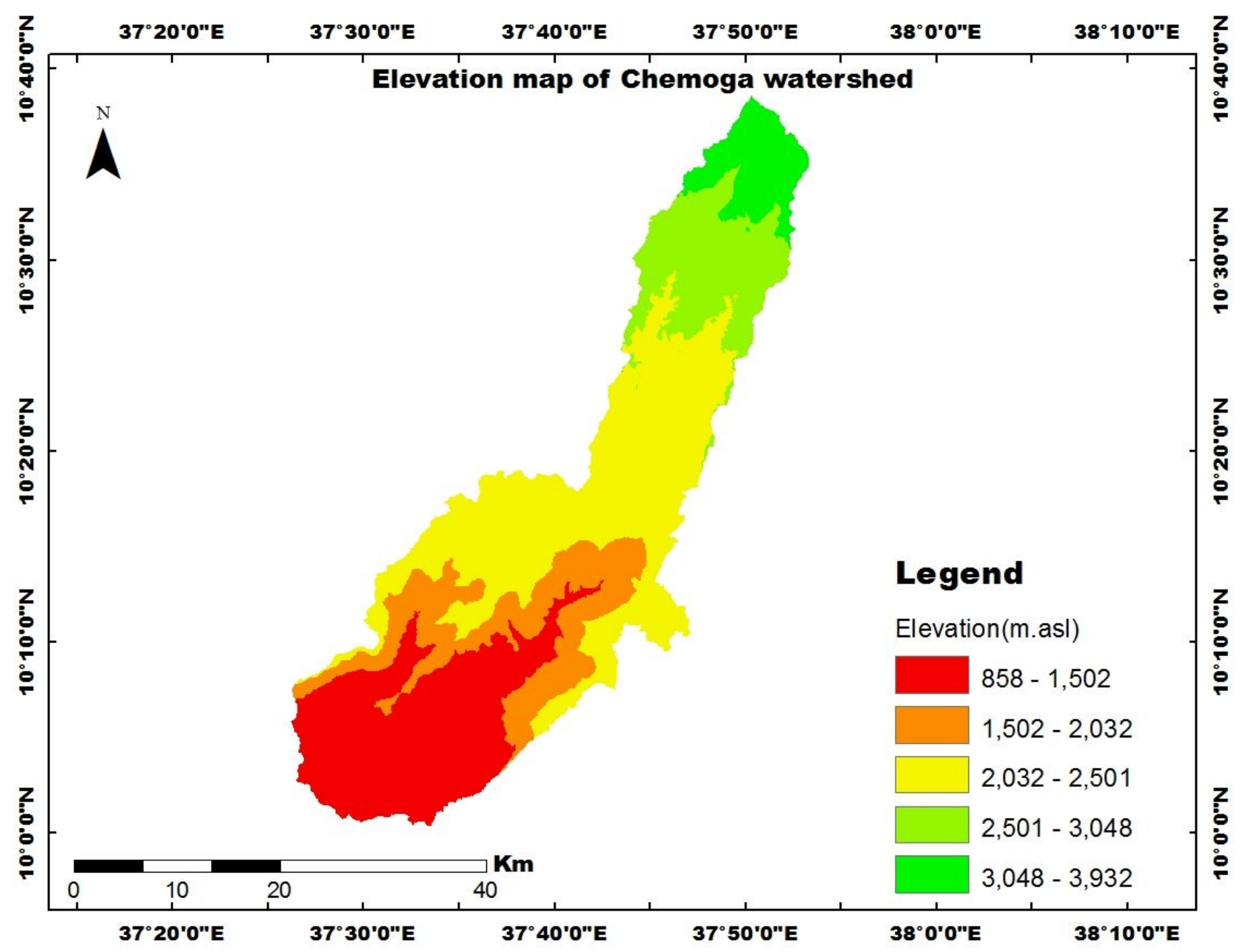

Figure 2

Raster elevation map of Chemoga watershed 


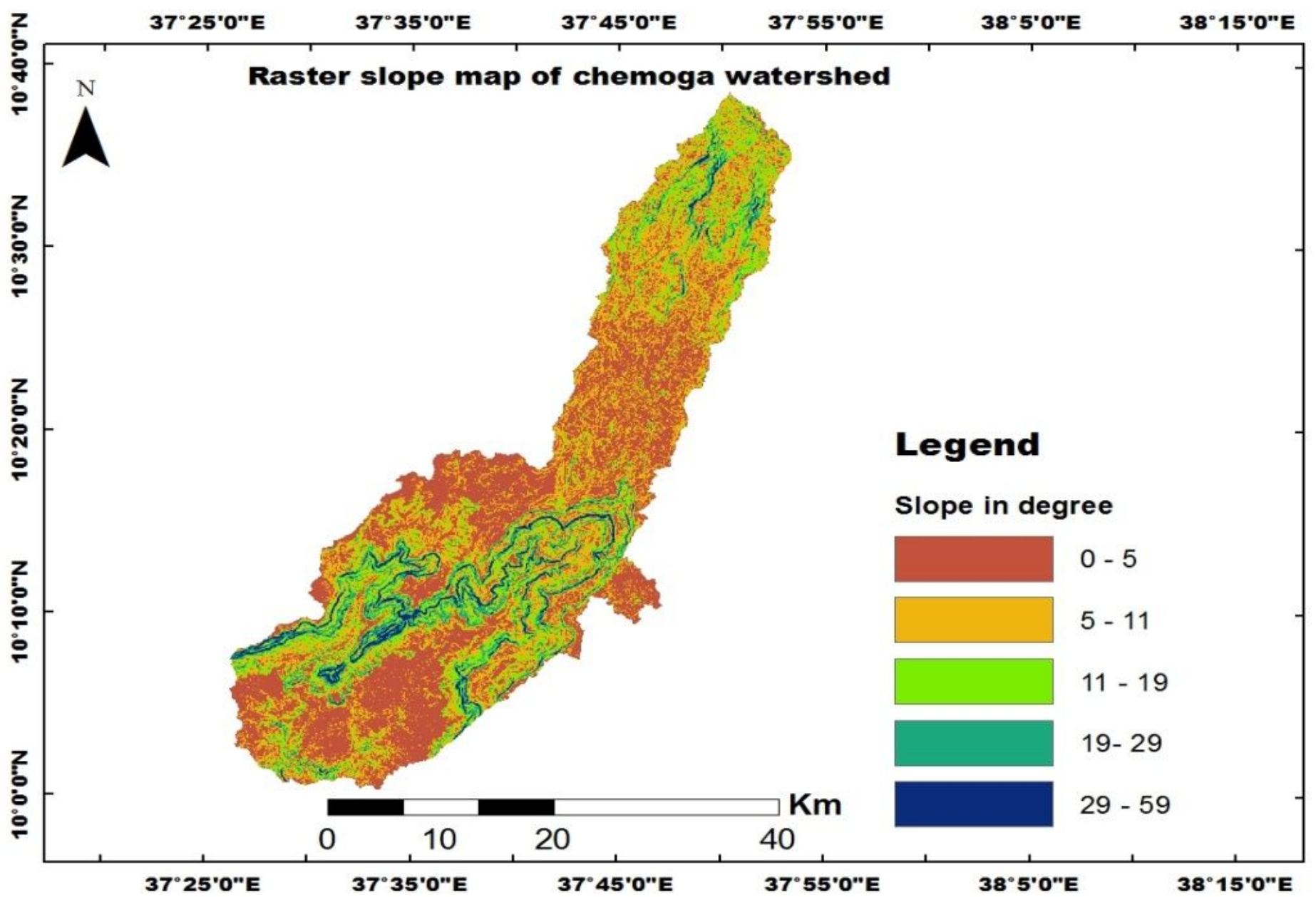

Figure 3

Raster slope map of Chemoga watershed 


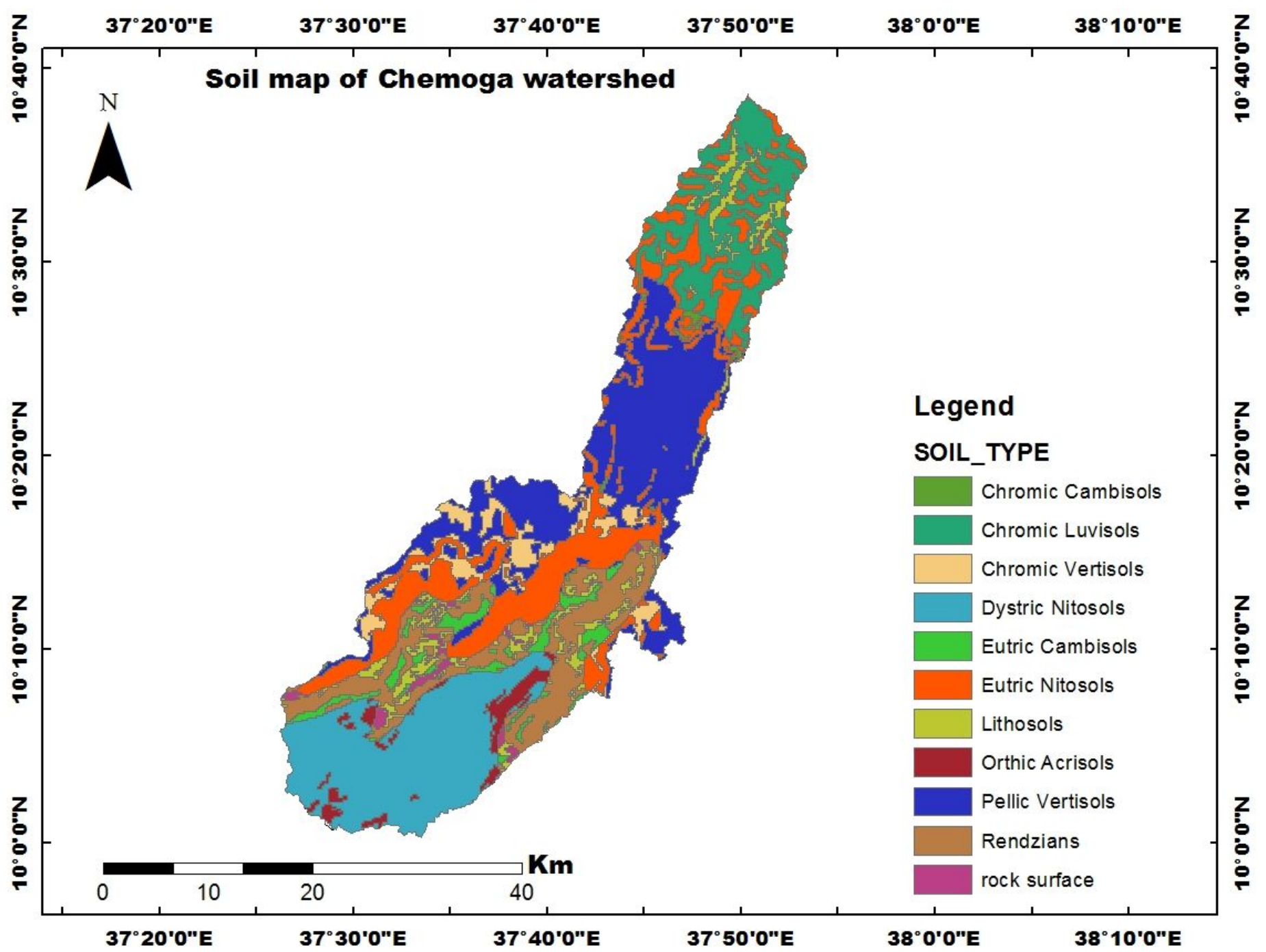

Figure 4

Raster Soil map of Chemoga watershed 


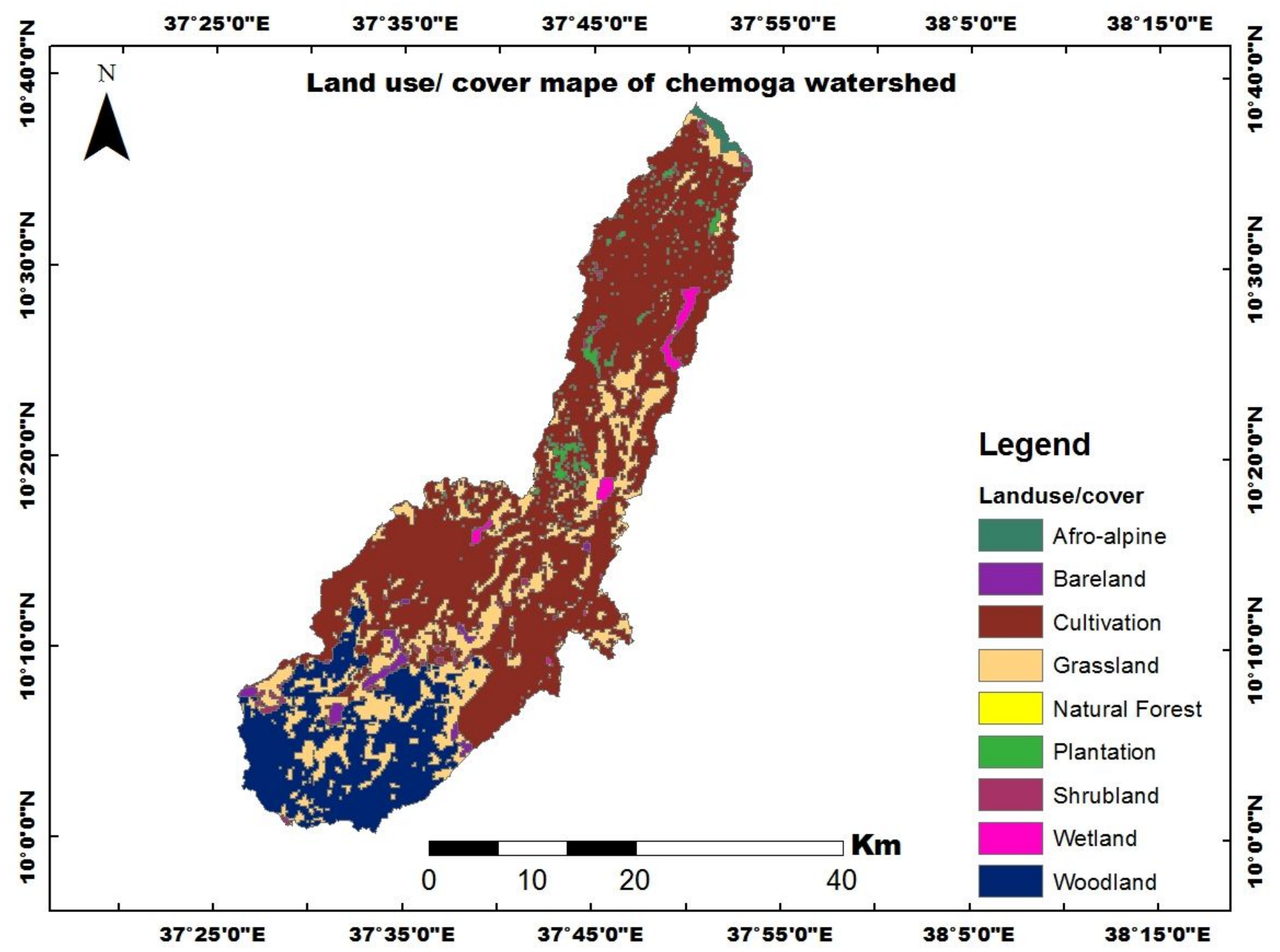

Figure 5

Raster land use land cover map of Chemoga watershed 


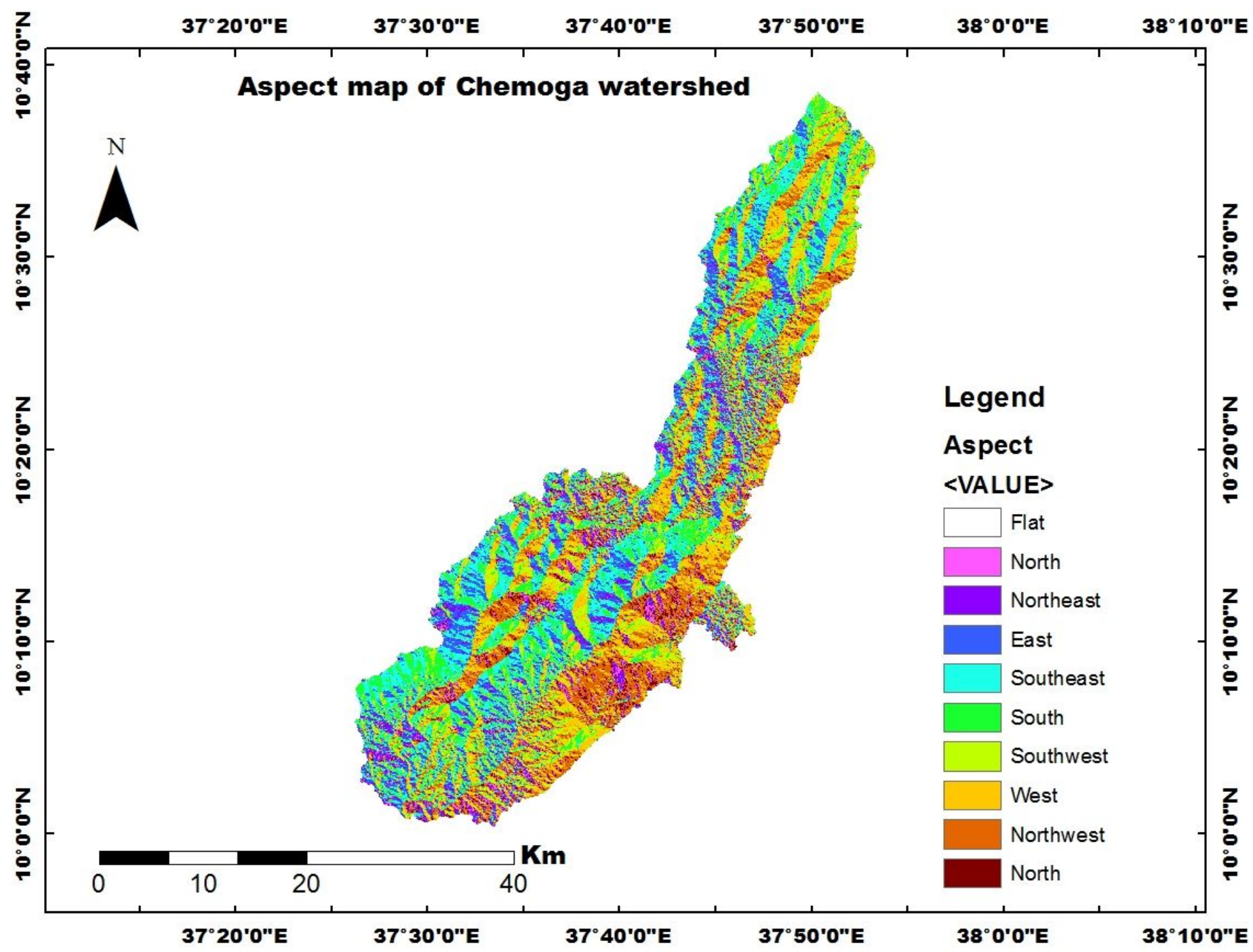

Figure 6

Raster aspect map of Chemoga watershed 


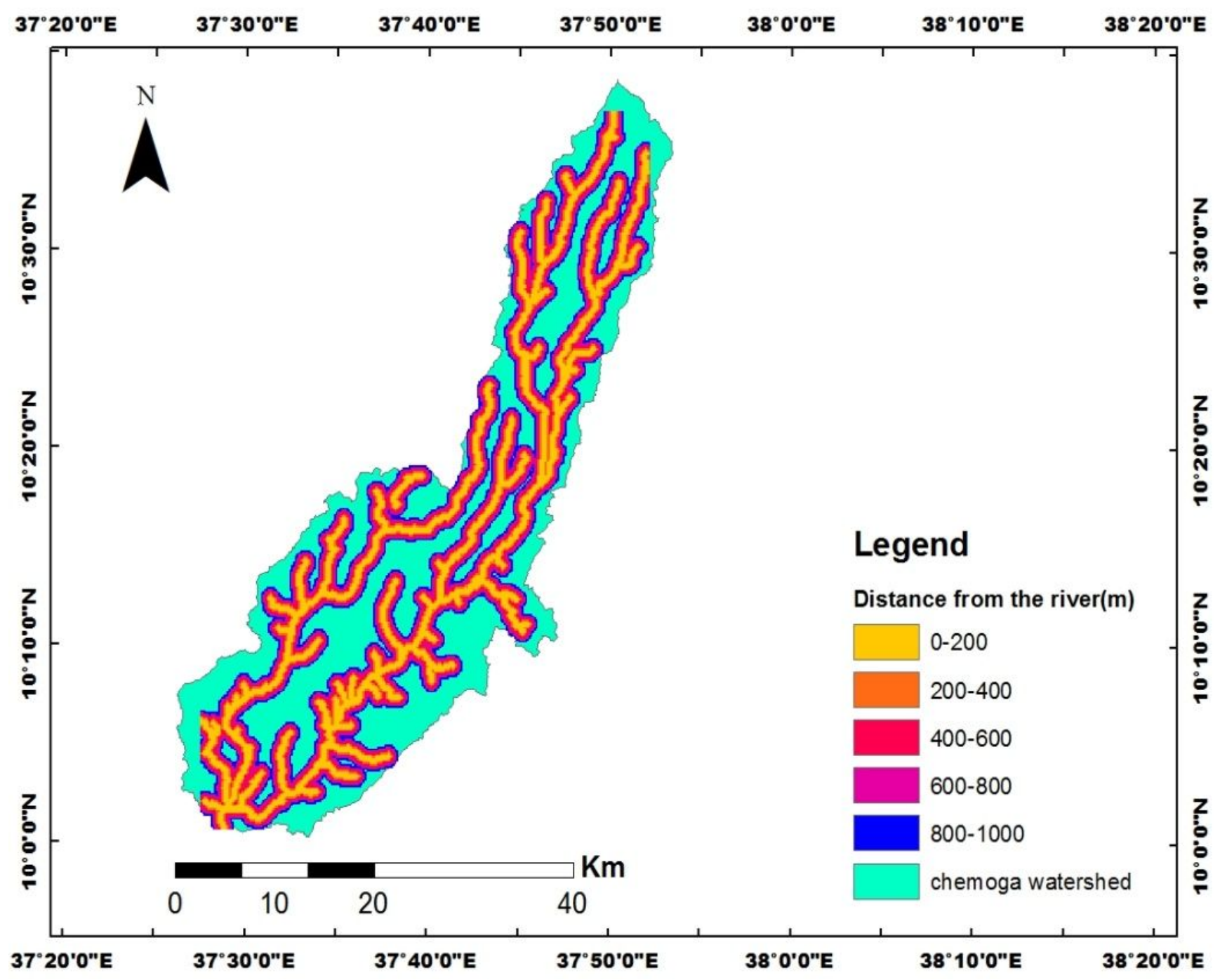

Figure 7

Raster distance to the river map of Chemoga watershed 


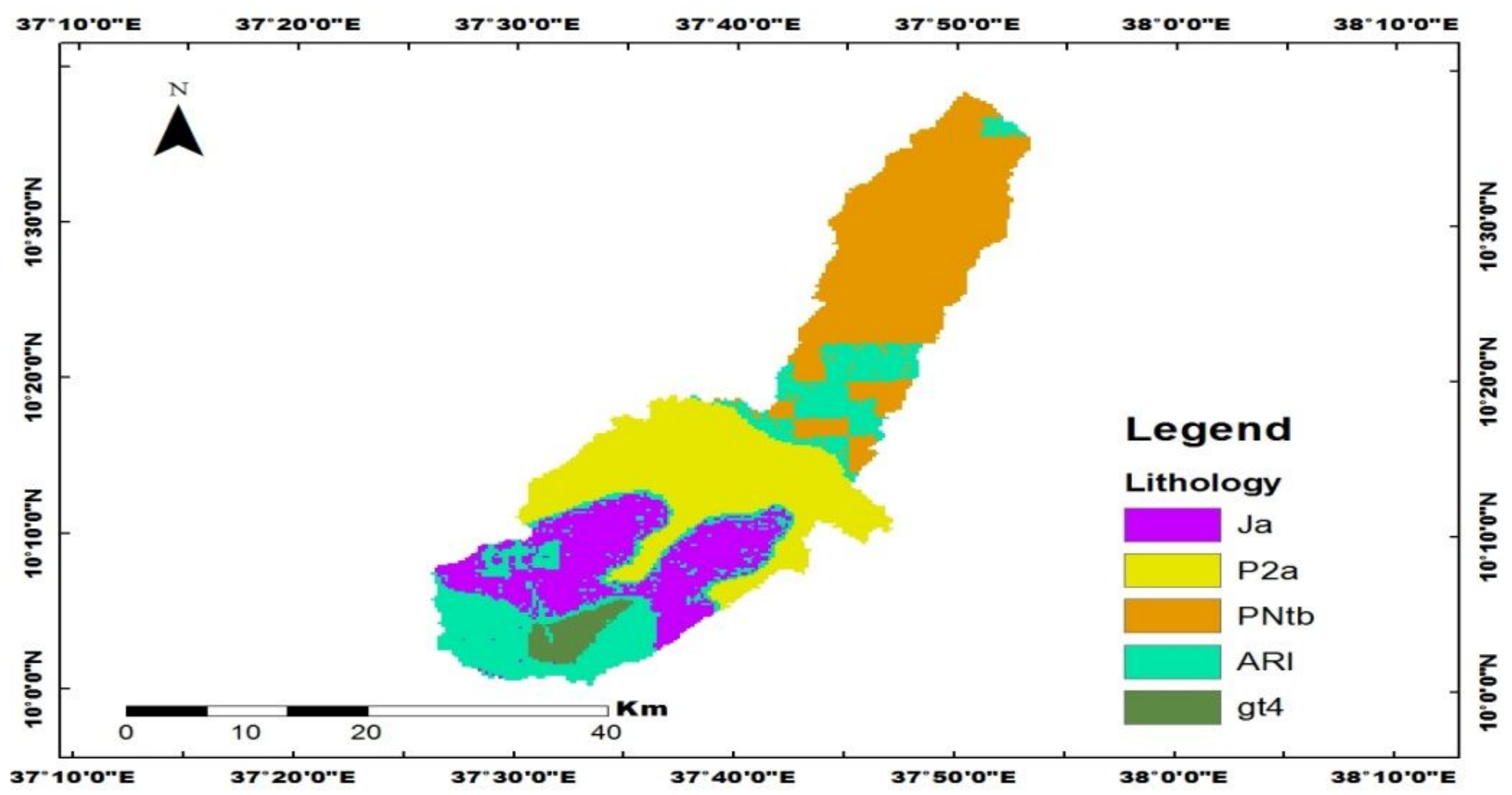

Figure 8

Raster lithology map of Chemoga watershed

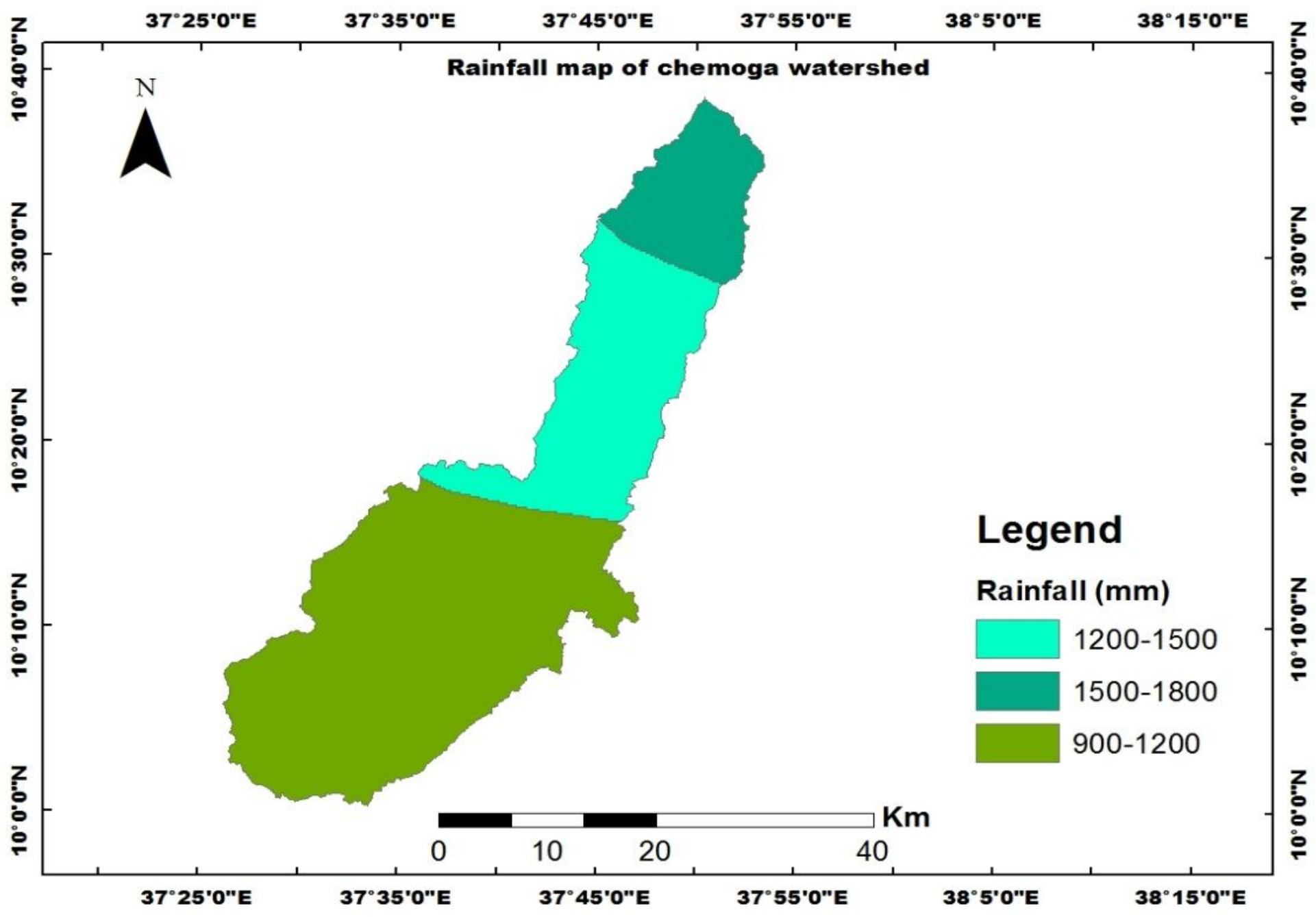


Figure 9

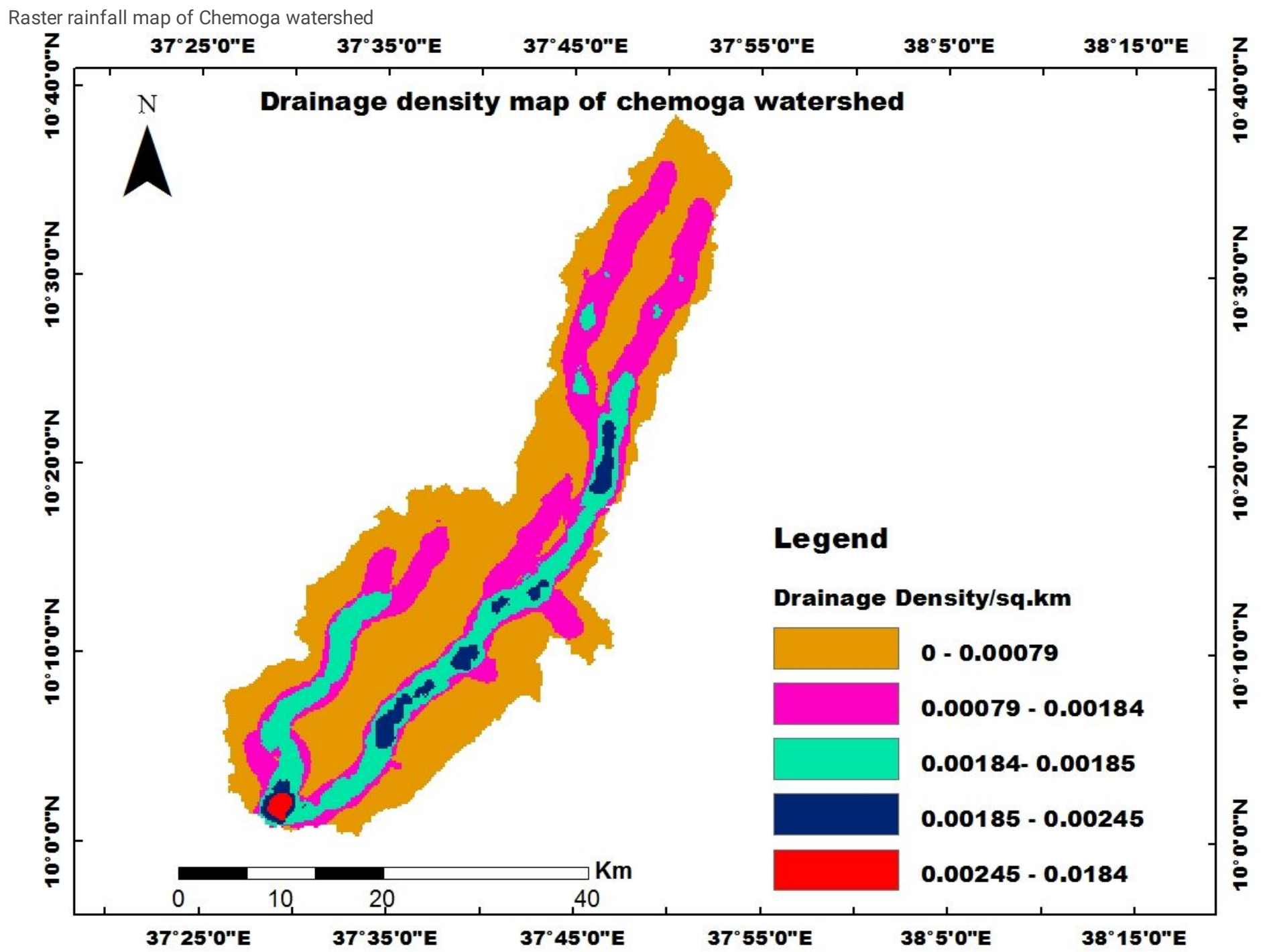

Figure 10

Drainage density map of Chemoga watershed 

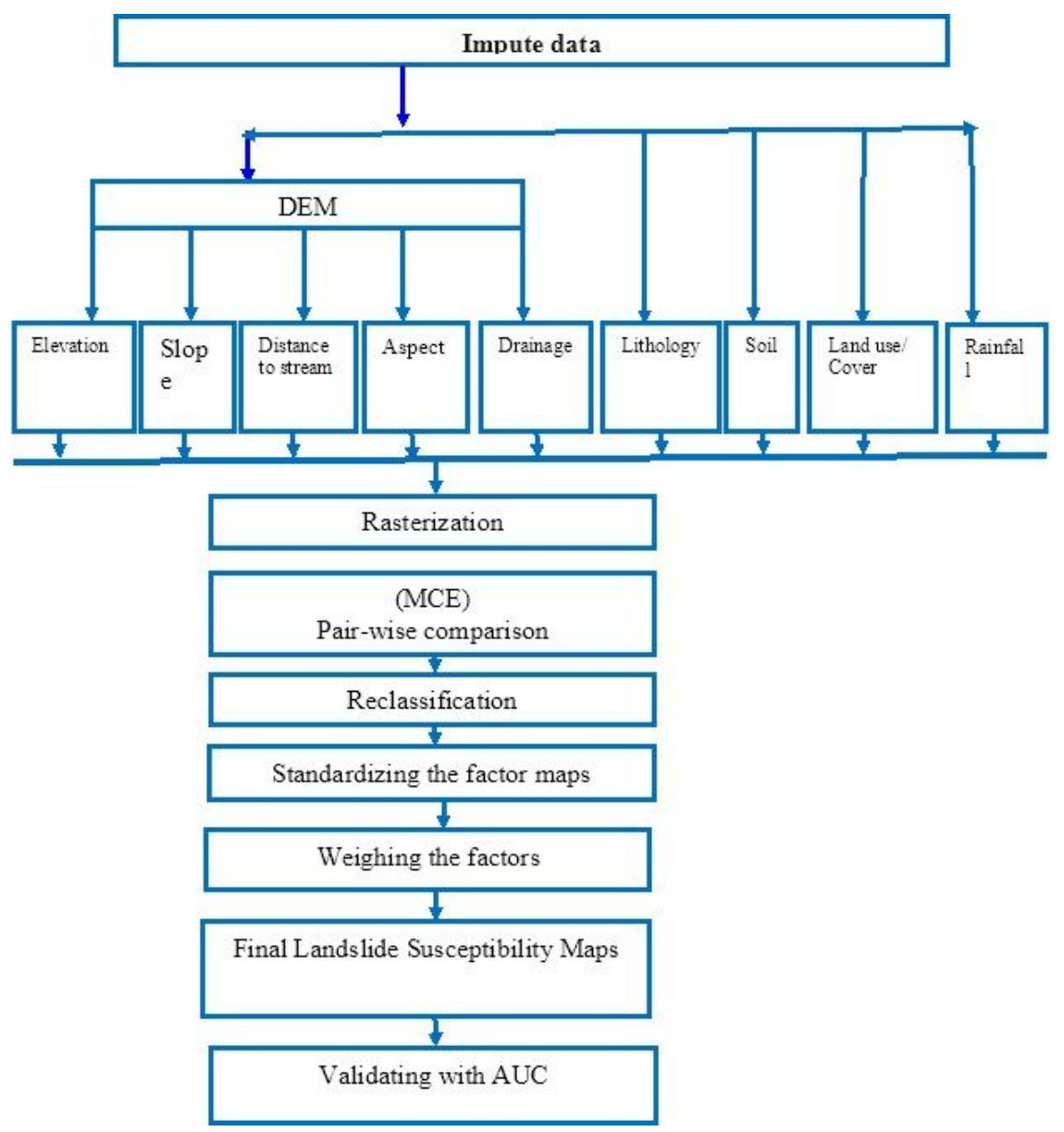

Figure 11

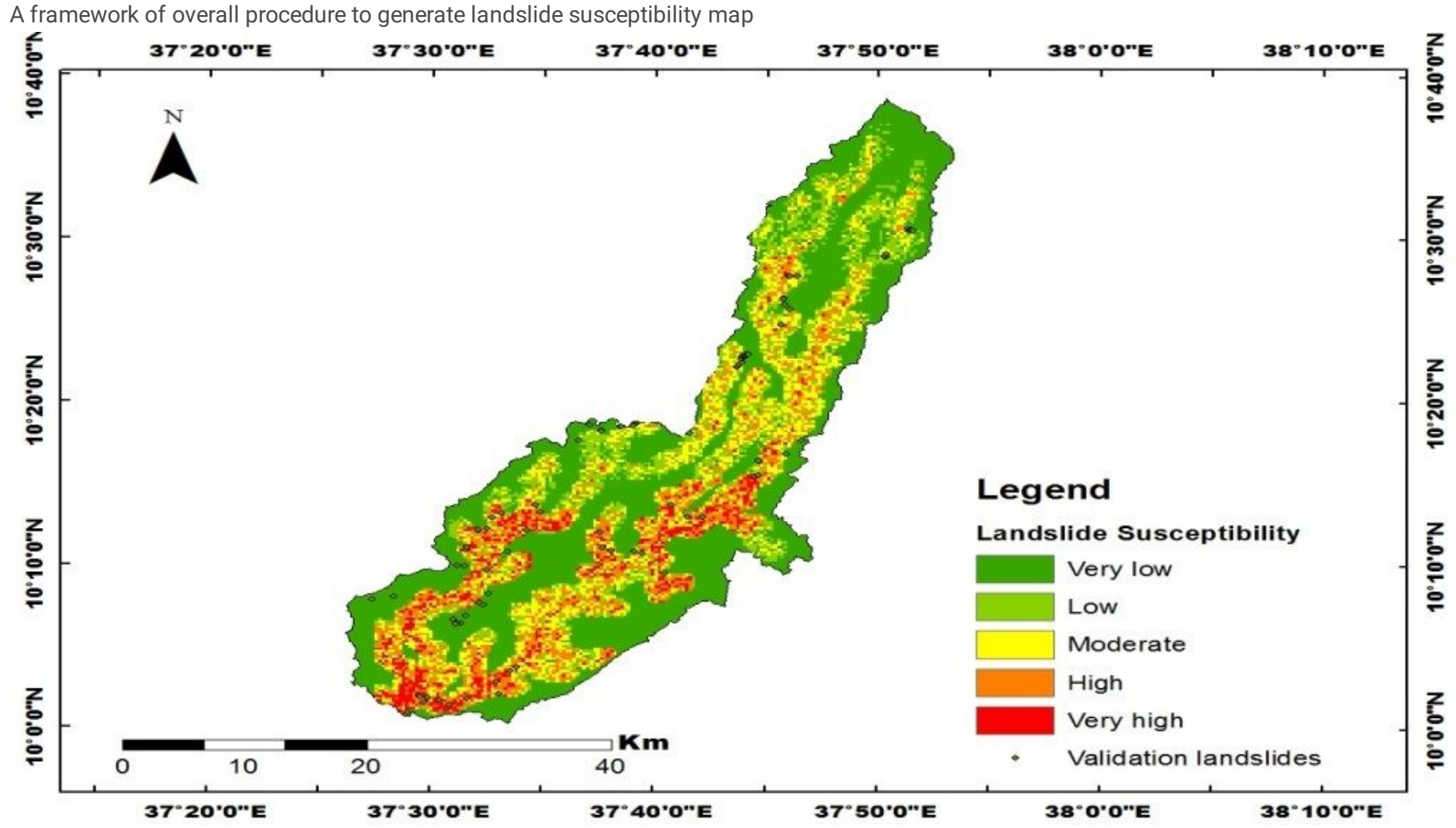

Figure 12

Landslide susceptibility map of Chemoga watershed 